
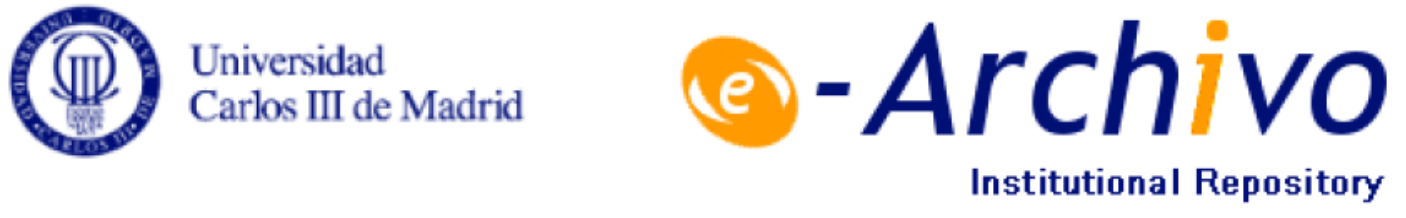

This is a postprint version of the following published document:

Stamatov, P. (2014). Beyond and against capitalism:

abolitionism and the moral dimension

of humanitarian practice. International Social Science Journal. 65 (215-216),

25-34

DOI: $\underline{10.1111 / \text { issj. } 12069}$

(C) Wiley, 2014 


\title{
Beyond and against capitalism: abolitionism and the moral dimension of humanitarian practice
}

\begin{abstract}
Peter Stama $Q$
How do we understand the origins of modern humanitarianism and what can these origins tell us about the study of humanitarianism in general? Pere I revisit a critical Jumeture of the formation of modern humanitarianism, the late 18th-century movement to abolish the British slave trade, through the lens of a prevailing paradigm that has explained it as deriving from the logic of capitalist development. A closer look at this early phase of abolitionism within its historical context

Peter Stamatov (peter.stamatov@nyu.edu) is Associate Professor of Social Research and Public Policy in the Social Science Division of New York University Abu Dhabi and Distinguished Researcher at the Carlos III/Juan March Institute of Social Sciences, Madrid. He is the author of the award-winning book The Origins of Global Humanitarianism: Religion, Empire, and Advocacy (2013) and has studied the interactions of culture, religion, and political action in the global context from a comparative historical perspective.
\end{abstract}

such as the economy. Reversing this assumption and directing attention to the casual influence of humanitarianism on other areas of social life eveals the implausibility of

opens up a promising field of scholarly inquiry.

\section{Abolitionism and the Marxist explanatory paradigm}

What was abolitionism and why is it a landmark in the trajectory of modern humanitarianism (Barnett 2011)? Consisting of three the economy as the most

solingt explanatory factor for the origin and success

$\Omega$ abolitionist project. Instead, this project emerged at the interstices of a complex causal entanglement between the areas of economic and moral action.

I conclude by drawing out the larger implications of this historical complexity for the study of humanitarianism at large. The inten abolitionism urges us to be more attentive to the manifold forms of humanitarian practice and to situate them in a proper causal context instead of assuming that humanitarianism is an epiphenomenal manifestation of allegedly deeper structural forces,

*I thank Iain Wilkinson, David Cook-Martín and the participants of the Social Trends Institute workshop on humanitarianism for their help in developing the argument presented here. public campaigns from 1788 onwards and resulting in the abolition of the trade in 1807 , abolition was the first highly visible, enduring and influential coupling of a humanitarian norm, the norm against slavery, with persistent institutions and practices (Brown 2006; Drescher 1987; Jennings 1997; Oldfield 1995). British abolitionism also exercised a formative influence on the complex phenomenon of humanitarianism. It generated recurrent campaigns against various slaveries in British colonies and then elsewhere; it became an important international "brand" of humanitarianism, as constituenof "their" slaveries; there is an almost unbroken continuity between the first London Abolition committee and today's Antislavery International; and abolitionism's rhetoric and organizational models were adopted widely by subsequent social movecies outside of Britain mobilised for the abolition ments, from the campaign against "factory slavery" 
in Yorkshire to the women's movement. More generally, the first abolitionist movement was able to gradually articulate a strict prohibitive moral regime against the slave trade and slavery and to force states, starting with the British state, and then international organisations to accept this regime. In short, abolitionism of the 1780 s was the sign of an important historical change, heralding the arrival of humanitarianism as we know it. In many ways, then, the proper understanding of the origins of modern humanitarianism depends on a proper understanding of the origins of these first abolitionist campaigns in the $1780 \mathrm{~s}$.

The idea that the primary cause for abolitionism was the capitalist transformation of the economy was enshrined in a series of canonical works initiated by Eric Williams's (1944) Capitalism and Slavery. Relying on a selective interpretation of the evidence, Williams explained the abolition of British colonial slavery in orthodox Marxist terms, arguing that by the time of its abolition in the $1830 \mathrm{~s}$ it had become a losing proposition for British capitalists. More careful examination of the economics of slavery and the slave trade showed, however, that neither was as inherently unprofitable nor as disadvantageous as to lead to its own abolition (Drescher 2010; Eltis 1987). As more detailed work in the economy of slavery and the slave trade made it increasingly clear that the abolition was impossible to explain on the grounds of economic rationality, scholars shifted their attention instead to non-economic yet economically determined factors that they thought were the important causal connection between the capitalist "base" and the abolitionist "superstructure" (Temperley 1977). For David Brion Davis ([1975] 1999) a capitalist ideological hegemony that was disturbed by ancient enslavement yet felt comfortable with Marx's "wage slavery" was that missing link. In another intervention in the debate, Thomas Haskell (1985) drew attention away from the functional fit between capitalism and oppression techniques to argue instead that what mattered was the extensive scale of capitalist economic transactions. Expanding markets required more sophisticated cognitive reckoning to account for complex economic transactions, according to Haskell, and humanitarian relating to distant others started to happen when people were able to transfer these cognitive skills to non-economic areas. Hence the origin of the moral concerns with colonial slaves.
What unites this historiographic tradition is an adherence to the Marxist postulate of the incompatibility of allegedly economically irrational slavery with the capitalist mode of production. On an even deeper level, the source of this tradition is Marx's insistence on the primary importance of relations of production as the ultimate causal factor in social dynamics. In Marx's model, no genuine and positive social change in the $19^{\text {th }}$ century was possible without the total transformation of a proletarian revolution, the cyclical equivalent of earlier "feudal" and "bourgeois" revolutions. Therefore, the activity of "reformers" and "humanitarians" was nothing more than the lukewarm effort of the bourgeois class to ensure its dominance by applying cosmetic remedies to capitalism's most severe social problems. In regard to abolitionism and antislavery, this Marxist disparagement of subrevolutionary reform expressed itself in exposing such movements as subservient to and dictated by the logic of capitalism. In the Marxist scheme, each productive system had its own corresponding system of oppression. Thus capitalism replaced the "ancient" and "medieval" oppressions of slavery and serfdom with the "modern" oppression of "wage slavery" in capitalist factories (Tucker 1978, p. 713,169 ). If abolitionism sought the ending of slavery and the slave trade, it was because these institutions were incompatible with the logic of the new capitalist order.

That the first abolition of the slave trade (if we discount the Danish abolition of its slave trade in anticipation of the impending British one) and then of slavery occurred precisely in the AngloAmerican world, the quintessential home of modern capitalism, strengthened the intuitive plausibility of this postulate. On the economic historians did not find evidence that slavery was inherently incompatible with capitalism. Thus historians were faced with a discrepancy: abolition did happen in the most developed capitalist contexts yet it was not clear that it was economic development that necessitated the abolition of slavery, because slavery was well integrated with the new capitalist order before its abolition. Scholars sought to resolve the tension between these two incompatible circumstances by crafting complex and nuanced causal schemes in order to ultimately prove - or indeed salvage against countervailing evidence the Marxian postulate about the ultimate role of the economy. Loosening up the causal rigour of a purely 
economic explanation, the strategy was to maintain the causal primacy of the economy by opening what was emerging as a black box of causal linkages and to find the specific feature of capitalism that created abolitionism.

Yet even these more complex casual schemes fail to satisfy. If, as Davis argued, Anglo-American industrialists and merchants joined abolitionism because of their ideological interest in instilling a more appropriate wage-based mode of oppression, why was it that their counterparts in contemporary France or late 19th-century Catalonia did the exact opposite and aligned themselves firmly with the pro-slavery camp (Fradera 1990; Gauthier 2007; Maluquer de Motes 1986; Quinney 1970, 1972)? In other words, Davis's postulated ideological connection between capitalism and abolitionism asserted itself selectively only in the Anglo-American case, which in itself requires an additional explanation.

Similarly, in a period when in Seymour Drescher's (1987, p.20) words, "capitalism provided the principal motives and the ideological underpinnings of British Atlantic slavery", British slave traders occupied the perfect position that should have made them - according to Haskell's logic - an illustration of the disciplinary power of the market to cultivate awareness of consequences and humanitarianism. In contrast, for example, with the monopoly exercised by the East India Company in the Indian Ocean area, the trade with Africa was open to individual investors, thus approaching the dream of the free market capitalist. While the African Company, supported financially by parliament, maintained the infrastructure of forts on the West African coast, the profits of the African trade were accessible after 1750 to anyone willing to invest in a trading voyage. In practical terms, this meant that British entrepreneurs involved in the slave trade by conducting complex and geographically spread operations in near freemarket conditions; were one of the most sophisticated market operators of their time (Behrendt 2001). They were the ideal market participants who, according to Haskell, would develop the preconditions for the new humanitarian sensibility: a cognitive proclivity for understanding long causal chains, a habitus of promise-keeping, and belief in the efficacy of one's actions.

Yet not a single one among them joined the abolitionist ranks. It is, of course, possible, although unlikely, that the market-embedded entrepreneurs engaged in the slave trade did develop the humanitarian sensibility hypothesised by Haskell but did not express it privately or publicly because of an overriding unconscious wish not to endanger their profits. The non-expression of such a hypothetical private conscience is, however, striking in light of the periodic public struggles over the organisation of the African trade in which various faction of African traders publicly debated various organisational alternatives and aired instances of abuses and corruption (Brown 2007; Keirn 1995; Klinge 1973). The main concern of all participants in these debates was the maximisation of the volume and the profit of the trade. Yet not a single time did the various factions of "African" merchants express even a fleeting acknowledgment of the suffering endured by enslaved Africans.

A similar selectivity can be seen at work among the Quakers, out of whose organisation the project of abolitionism originated. Both Davis and Haskell explain the Quakers' pioneering role in antislavery with their involvement as merchants and industrialists in the emergent capitalist market. Yet decisive for the Quaker turn towards antislavery was a culture of religious reformism carried out by a minority of reformers with a relative detachment from the workings of the market. By contrast, many of the British Quakers most invested in the economy, the economically successful Quakers of various trades, adopted the abolitionist programme under the intense pressure exercised by such reformers who were able to gradually overtake the governance organs of the Society of Friends (Brown 2006). Similarly important in the Quakers' case was a tradition of political activism. The small nucleus of Quakers who formed the first London abolition committee were entrepreneurs deeply embedded in business networks (Jennings 1997). Yet they were also engaged in the generational conflict within the Society of Friends between older and more conformist elders and a new cohort of more activist and socially conscious entrants in the elite (Brown 2006). One of them, James Phillips, was a highly successful printer and bookseller familiar with the workings of the market and, indeed, his business connections served him well in recruiting adherents to abolitionism (Jennings 1997; Oldfield 1995, p.43). Yet he was also the son of early "anti-war" activist Catherine Phillips, the travelling female Quaker minister who had spoken to members of the Pennsylvania legislature for cessation of hostility 
with Indians in a context when the majority of white Pennsylvanians clamoured for their 18thcentury equivalent of "war" on Indian "terrorists" (Phillips 1797). Again, the influence of a purely economic position was remarkably diluted here. Quakers, some of them indeed embedded deeply in a capitalist market, engaged in the movement against the slave trade not because they were capitalists, but because they were subjected to the pressure of fellow abolitionist reformers who in turn relied on a long-standing tradition of Quaker activist intervention in politics.

In short, these accounts of abolitionism result in a paradox. On the one hand they work rhetorically to reinforce the Marxist intuition that there must be something in capitalism that produces antislavery. At the same time numerous deviations from this postulated causal pattern appear if one is to search for an empirically testable causal link that would persuasively show the paramount influence of capitalism and economic determination on the actors of early abolitionism. The ultimate source of this tension is an implicit "oversocialised" model of social action where uniform attitudes are assumed to derive from a single overarching cause, such as capitalism, with no regard for the all too realistic possibility of either non-trivial variance in human responses to a single structural stimulus or multiple (and thus competing) causal influences. For while relaxing the strict parameters of the classic Marxist model and introducing an intermediate casual factor such as capitalist or humanitarian ideology, these authors still streamline their arguments along one single deterministic causal arrow that, flowing from the economic structures of capitalism, powerfully influences human behaviour.

\section{Abolitionism in its historical context}

These causal constructs are flawed in an even deeper sense because they misrepresent the complex relationship between two, at first sight, separate areas of purposive social action: the area of economic transactions and the area of moral action. A closer look at early British abolitionism reveals, however, the complex relationship between these two areas and how this complexity arose inevitably from the fact that the actors of abolitionism were not the oversocialised humans subjected to the totalising influence of capitalism but rather strategic and moral actors who confronted the economic realities of their time in a purposive manner.

To unpack this causal complexity it is necessary to consider, in their fullness, both the explanandum of abolitionism and the putative explanans of the economy. Abolitionism was not simply an "easy", sub-revolutionary, ameliorative or purely humanitarian project but a political and moral project of economic radicalism that sought successfully to transform the accepted moral calculus justifying an important part of the British economy. Nor can the new capitalism of the 18th century be reduced to a highly stylised realm of purely economic action driven exclusively by considerations of profitability and efficiency. It is only when we recognise the inherent complexity of both phenomena that we can evaluate the formative role of the economy for the rise of abolitionism.

Yet there is no sense in the works of the Marxist tradition, for example, of the complex meanings of the British slave trade that for its contemporaries, participants and observers alike. The commercial trading in enslaved Africans - the target of the abolitionist project - was remarkably modern economically and fit snugly with increasingly "capitalist" circuits of production, exchange, and consumption (Curtin 1990; Drescher 2010). The slave trade was neatly integrated in Atlantic commercial chains culminating in the delivery and re-export of highly demanded tropical products, such as the slave-produced sugar from the Caribbean. It was based on sophisticated financial machinery, such as bills of exchange and the West India brokerage houses in London that underwrote commercial transactions. It was lucrative for domestic investors, normally bringing them a stable return of slightly below 10 per cent. Indirectly, the trade provided employment for thousands producers throughout England (Anstey 1975; Checkland 1958; Klein 2010; McCants 2007; Morgan 2007; Porter 1970; Rawley 2005; Richardson 1987, 1998).

The slave trade was thus an inherently economic issue in that it was deeply connected with the larger economy. Yet, paradoxically, precisely because of its economic salience, the slave trade was also an inherently moral issue even before the rise of organised abolitionism in so far as the "African trade" (of which human cargo was the most profitable "commodity") formed one of the foci of ongoing political and moral debates on British foreign and imperial trade. Consolidating British 
capitalism, as a social formation, was not only a distinctive configuration of economic relations, but also a set of heterogeneous and contentious moral discourses, arguments, and ideologies. In the context of an imperially backed expanding foreign trade, moral polemics in the public sphere and in parliament constructed the perceived "value" of specific branches of that trade competing for the state and parliament's attention and resources. This politically constructed value of the trade was, in turn, increasingly important in an increasingly complex economic environment where ascertaining how profitable (and for whom) foreign trading activities were was an increasingly complex enterprise. Multiplying claims of competing economic groups produced a complex and contentious moral environment in which political battles over how exactly economic activities should be organised infused parliamentary politics and the public sphere (Bowen 1991; Bowen 2006; Brown 2007; Keirn 1995; Klinge 1973; Lipson 1931; Osborn 2002; Rawley 2005; Sutherland 1952; Van Aalst 1970).

In the historical context of abolitionism's emergence, the economic and the moral spheres were intertwined in complex ways and it is these complex interstices of moral struggles over economic issues that form the immediate explanatory background of abolitionism, not an abstract "capitalism". The fact of this intertwining complicates the basic Marxist explanatory plotline in which the economic environment "pushes" individuals towards certain thoughts and actions, such as the antislavery stance. That would have been the case if the economic area was, a priori, more fundamental and causally stronger than the sphere of moral reflection. Instead, the institutional arrangements of the economy were in many ways the result of political and thus inherently moral struggles. Potential 18th-century humanitarians were not simply the passive recipients of the impersonal forces of the "market". People in England were surrounded, if not enveloped, by ongoing cultural struggles over the moral meanings of markets and the economy.

It is impossible, in this context of ongoing moral debates on the economy, to reduce abolitionism to the expression of a market-produced humanitarian sensibility, as, for instance, Haskell attempts to do. The important innovation of the abolitionist ideological platform was not simply a new humanitarian focus on the suffering of the enslaved. The image of the suffering slave - in the abstract - was at that time a well-known trope of sentimental literature (Carey 2005). But the slave's condition was considered lamentable and sympathy-provoking yet natural and inevitable especially when enslaved labour in the colonies contributed to English economic power. The distinctive political "move" of early British abolitionism was to insist that the entire market in enslaved humans be abolished. Thus abolitionism had an inherent radical dimension that transcended the parameters of "pure" humanitarianism in two interrelated aspects. It reversed an existing moral calculus in which the negative "externalities" of distant enslavement were far outweighed by the benefits of the slave trade for the English economy and it demanded the immediate suspension of the slave trade, not its amelioration on humanitarian grounds. In addition to its humanitarian concern with enslaved Africans, abolitionism made two interconnected and novel claims: that enslavement was morally wrong regardless of its economic benefits; and, therefore, that the trade in enslaved humans had to be stopped immediately.

A market-generated generalised humanitarian disposition, however, would have been consistent with a number of other potential political projects of changing the parameters of the international slave trade. Counterfactually, one could imagine a vastly different target and outcome of the abolitionist project: for example, an international legal regime regulating the slave trade and ensuring some minimal "rights" to enslaved individuals that would guarantee them more humane treatment. In fact, there were several such ameliorative projects of regulating the slave trade and slavery in 18thcentury Britain (Brown 2006). Yet this is not what abolitionists envisioned and sought. As Charles James Fox argued in the first parliamentary debate on the abolition of the slave trade in 1789 , to compromise and just regulate the trade instead of fully abolishing it would be the equivalent of "regulation of robbery and restriction of murder" (House of Commons 1789b, p.194).

No ideology or disposition directly produced by capitalism can explain why enslaved Africans as opposed to other potential recipients of sympathy - formed such a strong focus of concern. In retrospect, it is tempting to explain this choice of humanitarianism's "target" with the assumption that there must have been something intrinsically and particularly heinous about slavery that 
automatically placed it so high on the moral agenda that it trumped other forms of suffering. But this is to rewrite history through the lens of the abolitionist normative framework that by now has become a commonsense moral intuition. It was the abolitionist ideology supported by an activist network that crystallised in the 1780 s that deliberately and successfully defined commercial transactions with humans in the role of commodity as an absolute moral wrong, against prevalent moral understandings that normalised enslavement bestlamentableyetultimatelyanindispensele and taken-for-granted aspect of the economy.

Illustrative examples of the general tenor of pre-abolitionist public discussions related to the British African help highlight the contrast between, on the one hand, the complacent moral climate into which abolitionism burst in in the $1780 \mathrm{~s}$, and, on the other hand, the truly radical dimension of the re-definition of the slave trade as an absolute moral wrong in need of immediate eradication. A propagandist of the slave trade exclaimed in 1745:

... is it not notorious to the whole World, that the Business of Planting in our British Colonies ... is carried on by the Labour of Negroes, imported thither from Africa? Are we not indebted to those valuable People, the Africans, for our Sugars, Tobaccoes, Rice, Rum, and all other Plantation Produce? And the greater the Number of Negroes imported to our Colonies, from Africa, will not the Exportation of British Manufactures among the Africans be in Proportion; they being paid for in such Commodities only? The more likewise our Plantations abound in Negroes, will not more Land become cultivated, and both better and greater Variety of Plantation Commodities be produced? As those Trades are subservient to the Well Being and Prosperity of each other; so the more either flourishes or declines, the other must be necessary affected ... (Postlethwayt 1745, p.6).

At the very same time he argued that that parliament's refusal to compensate the African Company's expenses for maintenance of trading forts in West Africa was a violation of rights that "would savour so barefacedly of the Tyranny and Oppression of the most slavish Countries" (Postlethwayt 1745). In 1777, a parliamentary petition of London traders accused the Committee of the African Company of encouraging "unjust practices of certain individuals" who undermined "the trade for Negroes to that part of the cost where the best Negroes ... are mostly to be got" (quoted in Klinge 1973, p.361). In 1772, Edmund Burke, who would later cultivate an abolitionist reputation, defended the African Company by arguing that under its management the number of "imported" slaves had increased more than twofold (quoted in Klinge 1979). As late as 1789 , petitions from Liverpool and Manchester for the preservation of slave trade in 1789 emphasised the inextricable connection between British production and the demand of the "African" trade to argue that an abolition would harm local artisans (House of Commons 1789a). Remarkably innocent of the parallels with the forced displacement of Africans, the Liverpool petitioners sought sympathy for "honest Artificers" whom abolition would degrade into "solitary Wanderers into the World, to seek Employment in Foreign Climes".

In other words, before the arrival of the abolitionist mobilisation, the British slave trade was considered typically as a purely economic or even "technical" topic and the focus was on its profitability and efficiency. There was rarely an expression of humanitarian concern for the enslaved: the human beings who were inflicted with a significant degree of suffering, degradation, and deprivation of basic liberties for the purposes of economic rationality. If there were publicly expressed concerns about the morality of the slave trade, they were about the putatively harmful ways in which aspects of the trade affected the British negatively, whether the economic wellbeing of the "nation" or of certain groups whose wellbeing and rights were undermined by the institutional arrangements of the trade.

We can find the occasional questioning of the moral foundations of the slave trade, such as Horace Walpole's 1750 letter that expresses passionate yet private disgust with the moral absurdity of the parliamentary proceedings establishing a new framework for the African Company:

We have been sitting this fortnight on the African Company: we, the British Senate, the temple of Liberty, and bulwark of Protestant Christianity, have this fortnight been pondering methods to make more effectual that horrid traffic of selling negroes [sic]. It has appeared to us that six and forty thousand of these wretches are sold every year to our plantations alone! - It chills one's blood - (Lewis et al. 1960, p. 126).

Yet disgusted as Walpole the MP (and other putative humanitarians at the time) might have been, he did not rise in the Commons to express a principled position against the slave trade. Publicly, the trade only turned into a moral problem in so far as it 
affected British interests and examination of the suffering it caused to the enslaved was relegated to the occasional private exercise of moral rigour.

The transformation that the rising abolitionist movement produced consisted thus in a radical reframing of the entrenched moral evaluation of the slave trade and in the normalizing of this reframing. From this new perspective, the trade was not evaluated according to how it benefited or harmed the profits of its British participants. Instead, abolitionism claimed, people in Britain - even those not connected directly with the economics of the slave trade - were deeply responsible for the absolute moral wrong of enslavement. It argued that the trade left an indelible moral stain on the nation, its government and parliament, all of them complicit in such inhumane and morally indefensible economic activity. As an early abolitionist pamphlet put it, "the revenue of the government, the profits of the merchants, and the luxury of the people have involved the whole nation as participes criminis" (Woods 1784, pp.22-23) in the maintenance of colonial slavery. "As Englishmen, the blood of the murdered African is upon us, and upon our children", exclaimed Thomas Cooper later (1787, p.28).

In addition to this substantive reversal of the habitual moral calculus, however, an important achievement of the abolitionist project was to take the absolutist moral argument of the wrongness of slavery from the recesses of private musings into the public arena. It gradually yet effectively broadcast and "normalised" the moral rigour of a minority that had developed - against the prevailing moral consensus - a far-reaching conviction that slavery was an evil to eradicate regardless of economic considerations. It turned a radical moral claim into a taken-for-granted commonsensical intuition that we still share.

It is impossible to explain the articulation and adoption of this economic radicalism by any overarching attitudinal or dispositional factor created by the logic of capitalism. Anything but the full abolition of the slave trade could have served humanitarians and capitalists of any hue very well, precisely because there were well established moral conventions that reconciled the existence of the perhaps lamentable condition of enslavement with a thriving and profitable capitalist economy.

In fact, recent work has emphasised the deeply heterogeneous and networked character of abolitionist constituencies that grew gradually by accretion (Palmer 2009; Stamatov 2013). It is impossible to define these constituencies along a single dimension determined by their economic position. Correspondingly, it is not realistic to expect a single causal path that led everyone to abolitions: the analytical task is to identify the distinctive motivations behind various individuals' and networks' adoption of the abolitionist cause.

What is more, explaining adherence to abolitionism from pre-existing uniform attitudes induced by capitalism may lead to circular reasoning. Individuals and groups might have engaged in proabolition activity not because of "deep" dispositions conditioned by capitalism, but simply because they engaged in what economists call "preference falsification" (Kuran 1995), that is, the public declaration of allegedly genuine individual preferences that are subtly tailored to what is considered socially acceptable. To put it simply, many of the signatories of the public petitions for the abolition of the slave trade might have given their signature not from intrinsic conviction but because they adopted the abolitionist cause under the subtle social pressure to conform to what they thought were the prevalent preferences of their peers. Research on how communities at the time transitioned between popular support of otherwise diametrically opposed radical and conservative causes only lends support to the importance of non-ideological contextual factors for popular political behaviour (Philp 1995). From this point of view, the important factor was not the pre-existing attitudes of the English, but the fact that the core of abolitionist organisers were able by various means to recruit a critical mass of supporters throughout England which, in turn, increased the social valuation of professed abolitionist preferences. It is quite likely that when they signed abolitionist petitions en masse the English were doing the historical equivalent of the "bucket challenge" of yesteryear: they were doing it because it was the popular thing to do, not because they were carriers of mindsets created by capitalism.

If there was one characteristic that united the disparate adherents of early abolitionism even more strongly than their embeddedness in a changing economy, it was their basic religious literacy that made them sensitive to the religious rhetoric of abolitionism. Central to the abolitionist platform was the centuries-old "prophetic" trope of a religious community that needs to amend its ways 
lest it suffer God's wrath. This "Hebraic" framing of slavery as sin for which the community has to expiate remained an enduring core of the abolitionist project from its emergence in mid18th-century transatlantic Quaker networks until much later into the 19th century (Stamatov 2013; Hulferey 2012). It was one persuasive way to connect discursively the economic and the moral and almost imperceptibly introduce a religious, and thus unassailable, justification for what was after all a rather unusual reform proposal. To the average English person of 1750 the abolition of the slave trade must have sounded as outlandish as the idea of legalised same-sex marriage to the average American two centuries later - precisely because the slave trade by that point had been justified by moral arguments that discounted the enslavement of Africans as an acceptable "price" to pay for British well-being. The Hebraic trope of the sinful nation reversed this moral calculus. The important point, however, is that for contemporaries the plausibility of this Hebraic framing did not require any distinctive attitude produced by capitalism, but just the basic biblical literacy that was the only universal trait shared by all inhabitants of the British Isles at the time.

In other words, early abolitionism is best understood as arising from the complex interplay of a variety of factors that include cultural framings that resonated with contemporaries and the autonomous dynamics of successful collective mobilisation. In itself, the economy, understood as a set of profit-oriented practices and structures, gives us no analytical leverage in understanding the origins of abolitionist economic radicalism or in answering the question why the abolitionist norm was adopted by a significant number of people. There is simply no plausible way to derive the distinctive salient features of the abolitions project directly or indirectly from economic structures. The pathways through which a distinctively "humanitarian" linkage between the economic and moral were created and disseminated were multiple and complex. They did not presuppose a single attitudinal disposition created by the rise of capitalism.

\section{Refocusing humanitarianism}

The deep question opened by the scholarly debate on the origins of abolitionism and antislavery is the precise nature of the connection between the economic and moral dimensions of human action. In practice, these two dimensions are inextricably connected: humans seek both material advantages and moral certainty. The analytical challenge then is to specify how they intersect to exercise causal influence on cognitions and actions. The general problem of the Marxist tradition in explaining abolitionism is its reliance on a convenient yet reductionist analytical shortcut: instead of exploring the complex intersections between the logics of the economic and the moral this tradition takes it for granted that capitalism and the economy form the bedrock structure that ultimately conditions and steers the moral dimension of action.

The historical irony in all this is that the scholarly tradition of economic derivatism was built on the shaky foundations of an error of Marx's. The presumably economically inefficient and premodern nature of slavery was an ideological trope, and thus inherently a moral statement, that the abolitionist project used in order to justify its goal, the abolition of slavery. It was at odds with economic and social facts: colonial slavery and the slave trade were generally highly profitable before their abolition; for the owner, the enslaved body had the double economic advantage of being capital and source of labour at the same time; in many settings slavery was compatible with industrial modes of production; and there is no indication that slavery was the predominant "ancient" mode of oppression (Drescher 2010; Fredrickson 1981; Price 1991; Starobin 1968; Wickham 1994). Yet Marx took this inherently moral statement and casually elevated it into an abstract principle of factual historical development. He mistook abolitionist rhetoric and the outcome of abolitionist action for the impersonal workings of large historical forces.

Colonial slavery, however, was not abolished because the impersonal forces of industrial capitalism did not need it. It was abolished because of temporally enduring and geographically spread waves of mobilisation that purposefully targeted its end (Drescher 2009). Within this larger and enduring abolitionist cycle of mobilisations, the early abolition campaigns in late 18th-century Britain were a critical event that built the initial base of later global abolitionisms.

Seen in this light, early abolitionism as a formative event in the history of global humanitarianism was a social phenomenon that exercised causal influences on its own. It did not 
produce the totalising effect of a "revolution" in Marx's eschatological sense. Yet it was an important step towards the transformation of global morality by successfully introducing a "prohibitive" regime against the enslavement of human beings (Nadelmann 1990). In other words, it gives its students strong reasons to leave behind the preconceptions of the Marxian legacy that sees abolitionism and humanitarianism as inherently derivative and thus sociologically uninteresting phenomena.

This is where the examination of the origins of abolitionism is suggestive for the study of humanitarianism in general. The clearest conclusion of the examination of these origins is the importance of a pervasive and irreducible moral dimension of the early abolitionist project with its focus on the complete ending of the slave trade as an absolute moral wrong. Abolitionism defined the condition of human enslaved as morally indefensible and after a series of complex interactions - transformed the global moral landscape. This moral dimension cannot be explained as deriving from the logic of economic transformations.

Recognising, analytically, the strong moral dimension of the abolitionist project, or any humanitarian project, does not mean its normative endorsement. A discussion of the inherent "rightness" of a moral norm and a moral conviction, while a legitimate endeavour, is beyond the scope of a sustained discussion of the analytical dimensions of humanitarianism's origin. Yet students and critics of humanitarianism will be well served by more focused attention to the inherently moral aspects of humanitarian projects, institutions, and practices in history and today. In that, they can count on the insights of scholars of social movements and international relations who in their own ways have highlighted the analytical importance of the moral dimension (Jasper 1997; Finnemore 1996).

My discussion shows that abolitionism stood in a complex, entangled, and antagonistic relationship with the economy. There is a twofold methodological lesson here: despite the instincts of the Marxian legacy, abolitionism was a causally significant, non-derivative phenomenon that needs, first, to be studied and understood in its complexity and, second, to be situated in a complex causal context. Extrapolated onto the wider field of humanitarianism in history, these two lessons call, first, for a better understanding of humanitarianism in the full variety and complexity of its manifestations and, second, for careful specification of the casual connections between existing humanitarianisms and other institutional spheres in various national and supranational arenas.

There is ample ground for a basic taxonomic and definitional work in the study of humanitarianism. What are the various forms of humanitarianism and how are they best defined (Wilkinson in this issue)? Even in an early manifestation, such as 18th-century British abolitionism, humanitarianism manifested itself in a variety of practices. Abolitionism had a distinctly political dimension in mobilising public opinion for pressure on parliament; it initiated economic projects for "alternative development" in Africa of economic activities to substitute the trading in human beings; and it developed a culture of selective consumption in Britain of "free produce" sugar and cotton, thus prefiguring contemporary practices of "fair trade". All these are related yet analytically distinct forms of humanitarian practice. The usual image of contemporary humanitarianism - partly the result of the visual propaganda of humanitarian agencies in a highly saturated market - is the seemingly apolitical narrative of aiding distant individuals suffering the consequence of catastrophic events. Yet even more so than in the 18th century, the global institutional field of humanitarianism is rich and complex. A first step of making humanitarianism sociologically interesting and rescuing it from the limiting assumptions of its derivative character involves sharper attention to the various organisational forms that constitute the humanitarian field today.

The historical dynamics of early British abolitionism cannot be fitted into an economically deterministic frame of explanation. The claim of the overwhelming causal effects of the economy is rather the scholarly elaboration of unwarranted assumptions made in the 19th century. What does this say about more recent statements about the subservient role of humanitarianism to capitalism (Chimni 2004; Donini 2010)? While it is quite possible that the causal force of the economy has increased remarkably in the recent past, this is a claim that needs to be proved, not taken for granted. Be that as it may, the lesson from the study of early abolitionism is that regardless of the exact nature of its relation with other spheres of society, humanitarianism has exercised causal effects on its own. The recognition of this fact opens up the 
possibility of exploring these causal effects and enriching the agenda of humanitarianism studies, especially if scholars venture to study the interface of humanitarianism with other institutional areas. What, for example, have been the effects of humanitarianism on concrete social phenomena such as labour, immigration, and social policies? More generally, how has humanitarianism contributed to the long-term process of normative and moral change? These are the kind of analytically fruitful questions that a careful examination of early abolitionism brings to our attention.

\section{References}

Anstey, R., 1975. The Atlantic slave trade and British abolition, 1760-1810. London:Macmillan.

BARNETT, M.N., 2011. Empire of humanity: a history of

humanitarianism. Ithaca, N.Y.: Cornell University Press.

Behrendt, S.D., 2001. Markets, transaction cycles, and profits: merchant decision making in the British slave trade. William \& Mary Quarterly, 58(1), 171.

Bowen, H.V., 1991. Revenue and reform: the Indian problem in British politics, 1757-1773. New York: Cambridge University Press.

Bowen, H.V., 2006. The business of empire: the East India Company and imperial Britain, 1756-1833.

Cambridge: Cambridge University Press.

Brown, C.L., 2006. Moral capital: foundations of British abolitionism. Chapel Hill: University of North Carolina Press.

Brown, C.L., 2007. The British Government and the slave trade: early parliamentary enquiries, 1713-83. Parliamentary History, 26, 27-41.

CAREY, B., 2005. British abolitionism and the rhetoric of sensibility. Basingstoke: Palgrave Macmillan.

CheCKLAND, S.G., 1958. Finance for the West Indies, 1780-1815. The Economic History Review, 10(3), 461-69.

CHImNi, B.S., 2004. International institutions today: an imperial global state in the making. European Journal of International Law, 15(1), 1-37.

COOPER, T., 1787. Letters on the slave trade: first published in Wheeler's
Manchester Chronicle and since reprinted with additions and alterations. Manchester: C. Wheeler.

Curtin, P.D., 1990. The rise and fall of the plantation complex: essays in Atlantic history. Cambridge: Cambridge University Press.

DAVIs, D.B., [1975]1999. The problem of slavery in the age of revolution, 1770-1823. New York: Oxford University Press.

DoninI, A., 2010. The far side: the meta functions of humanitarianism in a globalised world. Disasters, 34, S220-S37.

Drescher, S., 1987. Capitalism and antislavery: British mobilization in comparative perspective. New York: Oxford University Press.

Drescher, S., 2009. Abolition: a history of slavery and antislavery. Cambridge: Cambridge University Press.

Drescher, S., 2010. Econocide: British slavery in the era of abolition. 2nd ed. Chapel Hill: University of North Carolina Press.

ELTIS, D., 1987. Economic growth and the ending of the transatlantic slave trade. New York: Oxford University Press.

FinNemore, M., 1996. National interests in international society. Ithaca, NY: Cornell University Press.

Fradera, J.M., 1990. Limitaciones históricas del abolicionismo catalán In: F.D. Solano And A. Guimerá RAvINA, eds, Esclavitud y derechos humanos: la lucha por la libertad del negro en el siglo XIX. MADRID: Consejo Superior de Investigaciones Científicas.
FREDRICKSON, G.M., 1981. White supremacy : a comparative study in American and South African history. New York: Oxford University Press.

GAUTHIER, F., 2007. L'aristocratie de tépiderme: le combat de la société des citoyens de couleur, 1789-1791. Paris: CNRS.

HASKell, T.L., 1985. Capitalism and the origins of the humanitarian sensibility, part 1. The American Historical Review, 90(2), 339-61.

House OF Commons, 1789a. Journals of the House of Commons. H.M. Stationery Office.

House Of COMmons, $1789 \mathrm{~b}$. The Parliamentary Register; or History of the proceedings and debates of the House of Commons. London:

J. Debrett.

Huzzey, R., 2012. The moral geography of British anti-slavery responsibilities. Royal Historieal Seciefy (Lenden, England). Transactions of the Royal Historical Society, 22, 111-39.

JASPER, J.M., 1997. The art of moral protest: culture, biography, and creativity in social movements. Chicago: University of Chicago Press.

Jennings, J., 1997. The business of abolishing the British slave trade, 1783-1807. London: F. Cass.

KeIRN, T., 1995. Monopoly, economic thought, and the Royal African Company. In: J. BREWER ANP S. StAVES, eds, Early modern conceptions of property. London: Routledge.

KLeIN, H.S., 2010. The Atlantic slave trade. 2nd ed. New York: Cambridge University Press. 
KLINGe, D.S., 1973. The African Company in British politics, 1748-1783. Ithaca, New York: Cornell University.

KLINGE, D.S., 1979. Edmund Burke, Economical reform, and the Board of Trade, 1777-1780. The Journal of Modern History, 51(3), D1185-D200.

Kuran, T., 1995. Private truths, public lies: the social consequences of preference falsification. Cambridge, Mass., London, England: Harvard University Press.

Lewis, W.S., Smith, W.H. And Lam, G.L., 1960. Horace Walpole's correspondence with Sir Horace Mann. New Haven: Yale University Press.

LIPSON, E., 1931. The economic history of England. 5th ed. London: A. \& C. Black.

Maluquer de Motes, J., 1986.

Abolicionismo y resistencia a la abolición en la España del siglo XIX. Anuario de Estudios Americanos, 43, 311-31.

McCANTs, A.E.C., 2007. Exotic goods, popular consumption, and the standard of living: thinking about globalization in the early modern world. Journal of World History, 18(4), 433-62.

Morgan, K., 2007. Slavery and the British empire: from Africa to America. Oxford: Oxford University Press.

Nadelmann, E.A., 1990. Global prohibition regimes: the evolution of norms in international society. International Organization, 44(4), 489-526.

OldField, J.R., 1995. Popular politics and British anti-slavery: the mobilisation of public opinion against the slave trade, 1787-1807.

Manchester: Manchester University Press.
OldFIELD, J.R., 2013.Transatlantic abolitionism in the age of revolution: an international history of anti-slavery, c.1787-1820.

Osborn, J., 2002. India and the East India Company in the public sphere of eighteenth-century Britain. In: H.V. Bowen, M. LinColn and N. Rigby, eds, The worlds of the East India Company. Rochester, NY: Boydell Press.

Palmer, W., 2009. How ideology works: historians and the case of British abolitionism. The Historical Journal, 52(4), 1039-51.

Phillips, C.P., 1797. Memoirs of the life of Catherine Phillips: to which are added some of her epistles. London: Printed and sold by J. Phillips and son.

PHILP, M., 1995. Vulgar conservatism, 1792-3. English Historical Review, 110(435), 42-69.

PorTer, D.H., 1970. The abolition of the slave trade in England, 1784-1807. Hamden, Conn.: Archon Books.

Postlethwayt, M., 1745. The African trade, the great pillar and support of the British plantation trade in America. Stewey and anti-sleven: a transnational arehive Part 2: Slave trade in the Atlantic world. London: printed for J. Robinson,

PrICE, J.M., 1991. Credit in the slave trade and plantation economies. In: B.L. Solow, ed., Slavery and the rise of the Atlantic system. Cambridge: Cambridge University Press.

QuinNey, V., 1970. Decisions on slavery, the slave-trade and civil rights for negroes in the early French Revolution. Journal of Negro History, 55(2), 117-30.

QuinNeY, V., 1972. The problem of civil rights for free men of color in the early French Revolution. French Historical Studies, 7(4), 544-57.
Rawley, J.A., 2005. The transatlantic slave trade: a history. Rev. ed. Lincoln: University of Nebraska Press.

Richardson, D., 1987. The slave trade, sugar, and British economic growth, 1748-1776. Journal of

Interdisciplinary History, 17(4), 739-69.

Richardson, D., 1998. The British Empire and the Atlantic slave trade, 1660-1807. In: P.J. Marshall, ed., The Oxford history of the British Empire, Vol. 2: the eighteenth century. Oxford: Oxford Ur

Stamatov, P., 2013. Tme origins of global humanitarianism: religion, empires, and advocacy. New York: Cambridge University Press.

Starobin, R., 1968. Disciplining industrial slaves in the Old South. The Journal of Negro History, 53(2), 111-28.

SutherLand, L., 1952. The East India

Company in eighteenth-century politics. Oxford: Clarendon Press.

Temperley, H., 1977. Capitalism, slavery and ideology. Past and Present, (75), 94-118.

TuCKER, R.C., 1978. The Marx-Engels reader. New York: Norton.

Van Aalst, F.D., 1970. The British view of India, 1750 to 1785 . University of Pennsylvania.

Wіскнам, C., 1994. Land and power: studies in Italian and European social history, 400-1200 don: British School at Rome.

Williams, E., 1944. Capitalism and slavery. Chapel Hill: University of North Carolina Press.

Woons, J., 1784. Thoughts on the slavery of the negroes. London: James Phillips. 


\section{Queries}

Q1: Author: Please confirm that given names (red) and surnames/family names (green) have been identified correctly.

Q2: Author: Is this number correct?

Q3: Author: Word(s) missing here?

Q4: Author: Is this reference correct?

Q5: Auhtor:

publication details?

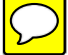

